\title{
Mechanism of action of antimicrobial peptide P5 truncations against Pseudomonas aeruginosa and Staphylococcus aureus
}

\author{
Ju Young Kwon ${ }^{1}$, Min Kyung Kim ${ }^{1}$, Loredana Mereuta ${ }^{2}$, Chang Ho Seo ${ }^{3}$, Tudor Luchian ${ }^{2 *}$ and Yoonkyung Park ${ }^{1,4^{*}}$
}

\begin{abstract}
Rates of microbial drug resistance are increasing worldwide; therefore, antimicrobial peptides (AMPs) are considered promising alternative therapeutic agents to antibiotics. AMPs are essential components of the innate immune system and exhibit broad-spectrum antimicrobial activity. P5 is a Cecropin A-Magainin 2 hybrid analog peptide with antimicrobial activity against Gram-negative and Gram-positive bacteria. In the present study, truncated peptides were designed to reduction length, retainment their antimicrobial activity and low toxicity at high concentrations compared with that of the parent peptide P5. The truncated peptides P5-CT1 and P5-NT1 exhibited antibacterial activities against both Gram-negative and Gram-positive bacteria. In contrast, P5-CT2, P5-CT3, P5-NT2, and P5-NT3 showed higher antibacterial activities against gram-positive bacteria compared to Gram-negative bacteria at low concentration of peptides. The truncated peptides showed lower hemolytic activity and toxic effects against mammalian cells compared with those of the parent peptide P5. The levels of several truncated peptides were maintained in the presence of physiological concentrations of salts, indicating their high stability. The results of flow cytometry, propidium iodide uptake, n-phenyl-1-naphthylamine uptake, and 3,3'-dipropylthiadicarbocyanine iodide assays showed that these truncated peptides killed microbial cells by increasing membrane permeability, thereby causing membrane damage. The results suggested that truncated peptides of P5 have good potential for use as novel antimicrobial agents.
\end{abstract}

Keywords: Antimicrobial peptide, Truncated peptide, Anti-biofilm, Mechanism of action

\section{Introduction}

Antimicrobial peptides (AMPs) are small molecules, 12-50 amino acids in length, and have been isolated from a variety of organisms, including animals, plants, bacteria, insects, and reptiles (Lehrer and Ganz 1999; Nawrot et al. 2014; van Hoek 2014). AMPs are secreted by, and are important for, the innate immune system (Devine and Hancock 2002; Hancock and Sahl 2006; Mendez-Samperio 2013); therefore, they have been used against a broad spectrum of invading pathogenic agents, such as bacteria, viruses, and fungi (Radek and Gallo 2007). Additionally, AMPs show anticancer activity towards stomach cancer,

\footnotetext{
*Correspondence: luchian@uaic.ro; y_k_park@chosun.ac.kr

${ }^{2}$ Department of Physics, Alexandru I. Cuza University, lasi, Romania

${ }^{4}$ Research Center for Proteineous Materials, Chosun University,

Kwangju 61452, South Korea

Full list of author information is available at the end of the article
}

lung carcinoma, acute T cell leukemia (Park et al. 2003), and colon cancer (Cho et al. 2018). Generally, AMPs contain $\alpha$-helical, $\beta$-sheet, and random coil secondary structures, which are necessary to form pores in bacterial membranes (Takahashi et al. 2010; Nguyen et al. 2011). Moreover, the net charge of AMPs is typically positive because of the presence of arginines and lysines (Brown and Hancock 2006; Jenssen et al. 2006), while the net charge of the bacterial membrane is negative. Therefore, AMPs are attracted to, and can disrupt, the bacterial membrane.

P5 is a Cecropin A-Magainin 2 (CA-MA, KWKLFKKIGIGKFLHSAKKF- $\mathrm{NH}_{2}$ ) hybrid analog peptide, and is a cationic 18-amino acid AMP. Cecropin A (CA) is a cationic 37-amino acid AMP that was isolated from Hyalophora cecropia pupae (Steiner 1982; Steiner et al. 2009). Magainin 2 (MA) is a cationic 23-amino acid AMP that 
was isolated from the skin of the African clawed frog, Xenopus laevis (Zasloff 1987). Cecropin A and Magainin 2 show high antimicrobial activities and no toxicity toward normal mammalian cells and red blood cells. A CA-MA hybrid peptide was constructed that combined residues 1 to 8 of $\mathrm{CA}$ and residues 1 to 12 of MA. The CA-MA hybrid peptide had high antimicrobial activity against bacteria and fungi (Oh et al. 2000; Park et al. 2003, 2006; Ryu et al. 2015). P5 (KWKKLLKKPLLKKLLKKL- $\mathrm{NH}_{2}$ ) was designed to have a high net positive charge and hydrophobicity by a flexible region (Gly-IleGly $\rightarrow$ P) substitution and Lys (positions $4,8,14,15$ ) and Leu (positions 5, 6, 12, 13, 16, 17, 20) substitutions (Park et al. 2003). P5 showed high antimicrobial activity against Gram-negative and Gram-positive bacteria and fungi, and anticancer activity in stomach cancer, lung carcinoma, and acute T-cell leukemia at low concentrations. However, P5 causes a low level of hemolysis of red blood cells and cytotoxicity in normal mammalian cells (Park et al. 2003; Ryu et al. 2011).

In the present study, the P5 peptide was truncated by two, four, and six amino acids at the C-terminal or N-terminal ends of the 18-amino acid parent peptide to design six truncated peptides, P5-C-terminus (CT)1, P5-CT2, P5-CT3, P5-N-terminus (NT)1, P5-NT2, and P5-NT3. We designed the P5 truncated peptides to have reduced length while retaining high antimicrobial activity and lower toxicity and hemolysis at high concentrations compared with those of the parent peptide P5. We compared the antibacterial activity, cytotoxicity, hemolysis effects, and anti-biofilm activity of the parent peptide with those of the truncated peptides. Our findings suggested that the P5 truncated peptides P5-CT1 and P5-NT1 could be developed as antibiotic therapeutic agents.

\section{Materials and methods Materials}

Lipopolysaccharide (LPS; from Pseudomonas aeruginosa), Lipoteichoic acid (LTA; from Staphylococcus aureus), 3-(4,5-dimetylthiazol-2-yl)-2,5-diphenyltetrazolium bromide (MTT), dimethyl sulfoxide (DMSO), propidium iodide (PI), n-phenyl-1-naphthylamine (NPN), HEPES, and 3,3'-dipropylthiadicarbocyanine iodide $\left(\mathrm{DisC}_{3}-5\right)$ were obtained from Sigma-Aldrich (St Louis, MO, USA).

Pseudomonas aeruginosa ATCC 27853 and Staphylococcus aureus ATCC 25923 were obtained from the ATCC (American Type Culture Collection, Manassas, VA, USA), and Acinetobacter baumannii KCTC 2508 and Bacillus subtilis KCTC 2217 were obtained from the KCTC (Korean Collection for Type Cultures, Jeongeupsi, Jeollabuk-do, Korea). Human skin epithelial cells ( $\mathrm{HaCaT}$ cells) were obtained from ATCC.

\section{Peptide design}

We designed six peptides, P5-CT1, P5-CT2, P5-CT3, P5-NT1, P5-NT2, and P5-NT3, by truncating P5 based on a helical wheel projection and its three-dimensional structure. Amino acid sequence analysis of peptides was conducted using the Mobyle@RPBS bioinformatics portal (http://mobyle.rpbs.univ-paris-diderot.fr/cgi-bin/ portal.py\#welcome) and the HeliQuest site (http://heliq uest.ipmc.cnrs.fr).

\section{Circular dichroism spectra analysis}

Circular dichroism (CD) spectra were measured to investigate the secondary structure of peptides in membrane mimic environments. Each peptide was dissolved at $80 \mu \mathrm{M}$ in $30 \mathrm{mM}$ sodium dodecyl sulfate (SDS), 50\% trifluoroethanol (TFE), or $10 \mathrm{mM}$ sodium phosphate buffer (SP buffer $\mathrm{pH}$ 7.2). In addition, the secondary structures of the peptides were measured in the presence of $500 \mu \mathrm{g} / \mathrm{mL}$ LTA and LPS. The CD spectra were measured from 190 to $250 \mathrm{~nm}$ using a 1-mm quartz cuvette with a JASCO 810 spectropolarimeter (Jasco, Tokyo, Japan).

\section{Antimicrobial activity}

We detected the antimicrobial activity of peptides against Gram-negative bacteria (P. aeruginosa ATCC 27853 and A. baumannii KCTC 2508) and Gram-positive bacteria (S. aureus ATCC 25923 and B. subtilis KCTC 2217). The minimum inhibitory concentrations (MICs) of the parental and truncated peptides were determined using the microbroth dilution method, as previously described (Jorgensen 1993). The bacteria were incubated overnight with shaking at $37{ }^{\circ} \mathrm{C}$. The bacteria were diluted to $2 \times 10^{5}$ colony forming units $(\mathrm{CFU}) / \mathrm{mL}$ in MuellerHinton broth (MHB) media. The peptides were serially diluted in $10 \mathrm{mM}$ sodium phosphate buffer and then 50 $\mu \mathrm{L}$ of the bacteria and $50 \mu \mathrm{L}$ of the peptide solutions were mixed and incubated for $18 \mathrm{~h}$ at $37{ }^{\circ} \mathrm{C}$. The MICs were measured as the absorbance at $600 \mathrm{~nm}$ using a Versa Max microplate reader (Molecular Devices, Sunnyvale, CA, USA). The samples were analyzed in triplicate.

\section{Time-kill kinetics assay}

The kinetics of the antibacterial activity of the peptides against $P$. aeruginosa ATCC 27853 and S. aureus ATCC 25923 were assessed. Bacteria grown to mid-log phase were diluted to $2 \times 10^{5} \mathrm{CFU} / \mathrm{mL}$ in MHB media. Peptides at $1 \times$ and $2 \times$ their MICs were added to the bacteria at $37^{\circ} \mathrm{C}$ and aliquots of the bacteria were spread on MHB agar plates. The plates were incubated at $37{ }^{\circ} \mathrm{C}$. After overnight culture, the CFUs of bacteria were counted. The results were expressed as the cell survival percentage. 


\section{Anti-biofilm activity}

Pseudomonas aeruginosa ATCC 27853 and S. aureus ATCC 25923 were cultured in MHB media. Bacteria were diluted in MHB media containing $0.2 \%$ glucose at $5 \times 10^{5} \mathrm{CFU} /$ $\mathrm{mL}$ and the diluted bacteria and peptides were added to a 96-well plate, which was incubated at $37^{\circ} \mathrm{C}$. After $24 \mathrm{~h}$, the supernatant was discarded, and biofilms were fixed with $100 \%$ methanol for $15 \mathrm{~min}$. The methanol was removed and the biofilms were stained with $0.1 \%$ crystal violet for $30 \mathrm{~min}$, after which the crystal violet was rinsed with distilled water. Next, $200 \mu \mathrm{L}$ of $95 \%$ ethanol was added to each well to dissolve the biofilm. After $1 \mathrm{~h}$, the biofilm inhibition activity was measured as the absorbance at $595 \mathrm{~nm}$ using a Versa Max microplate reader.

\section{Hemolytic activity}

To determine the hemolytic activities of the peptides against red blood cells (RBCs) from mice, RBCs were centrifuged at $2000 \times g$ for $5 \mathrm{~min}$ and washed with $1 \mathrm{~mL}$ of phosphate-buffered saline solution (PBS) three times. The supernatant was removed and the RBCs were diluted to $8 \%$ in PBS. After serial dilution, $60 \mu \mathrm{L}$ of the RBCs and peptides were added to a 96-well plate and incubated at $37{ }^{\circ} \mathrm{C}$ for $1 \mathrm{~h}$. The plate was centrifuged at $1500 \times g$ for $10 \mathrm{~min}, 100 \mu \mathrm{L}$ of the supernatant was transferred to a new plate, and the absorbance was measured at $414 \mathrm{~nm}$ (Versa-Max enzyme-linked immunosorbent assay (ELISA) reader). Additionally, 0.1\% Triton X-100 and PBS were used as positive and negative controls, respectively. The hemolytic activity percentage (hemolysis rate) was calculated using the following equation (Han et al. 2016):

$$
\begin{aligned}
& \text { Hemolysis percentage }(\%) \\
& =[(\text { peptide solution }- \text { negative control }) /(\text { positive control }-\mathrm{PBS})] \\
& \times 100
\end{aligned}
$$

\section{Cell culture and cytotoxicity assay}

Human skin epithelial cells ( $\mathrm{HaCaT}$ cells) were cultured in Dulbecco's modified Eagle's medium (DMEM) with $10 \%$ fetal bovine serum (FBS) at $37{ }^{\circ} \mathrm{C}$ in $5 \% \mathrm{CO}_{2}$. Cytotoxicity was determined using the MTT assay (Deng et al. 2015). $\mathrm{HaCaT}$ cells were plated at $2 \times 10^{4}$ cells/ well in 96-well plates. After overnight incubation, the peptides were added at various concentrations for $24 \mathrm{~h}$, and then $5 \mathrm{mg} / \mathrm{mL}$ of MTT was added to each well. After $1 \mathrm{~h}$, the supernatant was removed and $100 \mu \mathrm{L}$ of DMSO was added to each well to dissolve the formazan crystals. Cytotoxicity was measured at an absorbance of $570 \mathrm{~nm}$ using a microplate reader (VersaMax). The cell viability percentage (cell viability rate) was calculated using the following equation (Kim et al. 2018):

\section{Salt sensitivity}

The effects of various cations on the antimicrobial activity of P5 and the truncated peptides were determined against P. aeruginosa ATCC 27853 and S. aureus ATCC 25923. Bacteria were treated with the peptides in the presence of $\mathrm{NaCl}(50,100$, and $150 \mathrm{mM}), \mathrm{MgCl}_{2}(0.5,1$, and $2 \mathrm{mM})$, and $\mathrm{FeCl}_{3}(1,4$, and $8 \mu \mathrm{M})$. The $\mathrm{MIC}$ values were the same as those described above.

\section{Propidium iodide uptake assay}

To assess whether the peptides target the bacterial membrane, we performed a propidium iodide (PI) uptake assay. P. aeruginosa ATCC 27853 and S. aureus ATCC 25923 were cultured to mid-log phase in MHB media and diluted to an optical density at $600 \mathrm{~nm}\left(\mathrm{OD}_{600}\right)$ of $0.27 \mathrm{in}$ MHB media. Bacteria were mixed $20 \mu \mathrm{g} / \mathrm{mL}$ of PI (final concentration: $10 \mu \mathrm{g} / \mathrm{mL}$ ) and $50 \mu \mathrm{L}$ of bacteria were added to each well. Next, $50 \mu \mathrm{L}$ of peptides at different concentrations was added to each well. PI fluorescence was measured at excitation and emission wavelengths of 580 and $620 \mathrm{~nm}$, respectively.

\section{Outer membrane permeability assay}

Outer membrane (OM) permeability was determined by measuring NPN uptake (Loh et al. 1984). P. aeruginosa ATCC 27853 was cultured to mid-log phase in MHB media. The bacteria were washed and resuspended to an $\mathrm{OD}_{600}$ of 0.2 in $5 \mathrm{mM}$ HEPES (pH 7.2). Next, $100 \mu \mathrm{L}$ of the bacteria suspension was mixed with $50 \mu \mathrm{L}$ of $8 \mu \mathrm{g} / \mathrm{mL}$ NPN (final concentration: $2 \mu \mathrm{g} / \mathrm{mL}$ ) and different concentrations of the peptides in a 96-well black plate. NPN fluorescence was measured at excitation and emission wavelengths of 350 and $420 \mathrm{~nm}$, respectively.

\section{Cytoplasmic membrane depolarization assay}

The membrane depolarization activities of the peptides were detected using $P$. aeruginosa ATCC 27853 and S. aureus ATCC 25923, together with the membrane potential-sensitive fluorescent dye $\mathrm{DisC}_{3}-5$, as previously described (Han et al. 2013). Briefly, the bacteria were cultured to mid-log phase in MHB media and washed with $5 \mathrm{mM}$ HEPES buffer containing $20 \mathrm{mM}$ glucose. Bacteria were resuspended to an $\mathrm{OD}_{600}$ of 0.05 in a $5 \mathrm{mM}$ HEPES buffer containing $20 \mathrm{mM}$ glucose and $0.1 \mathrm{M} \mathrm{KCl}$, and then $\mathrm{DisC}_{3}-5$ (final concentration: $1 \mu \mathrm{M}$ ) (Kim et al. 2018) was added to each well. After $1 \mathrm{~h}$ of incubation, the mixture was left to stand; when the reduction in the fluorescence of the mixture was stable, the peptides were added to each well. The fluorescence was measured at

Cell viability percentage $(\%)=($ peptide treated sample $)-($ no peptide treated control $)$ $\times 100$. 
excitation and emission wavelengths of 622 and $670 \mathrm{~nm}$, respectively.

\section{Flow cytometry}

Damage to the bacterial membrane was evaluated using flow cytometry. Briefly, P. aeruginosa ATCC 27853 and S. aureus ATCC 25923 were grown to mid-log phase in MHB media and then washed three times with PBS. The bacteria were diluted to an $\mathrm{OD}_{600}$ of 0.26 in MHB media. The bacteria were treated with $1 \times$ MIC and $2 \times$ MIC of the peptides and with PI at a final concentration of $10 \mu \mathrm{g} /$ $\mathrm{mL}$, followed by incubation for $30 \mathrm{~min}$ at $37^{\circ} \mathrm{C}$. The bacteria were centrifuged at $13,000 \times g$ for $5 \mathrm{~min}$ and resuspended in $500 \mu \mathrm{L}$ of PBS. The samples were analyzed using a CytoFLEX flow cytometer (Beckman Coulter, Brea, CA, USA).

\section{Statistical analysis}

All data represented from triplicate individual experiments. The results of hemolysis and cytotoxicity were analyzed using $t$-test. Mean differences at $" p<0.05$, *** $p<0.01$ were considered significant.

\section{Results}

\section{Peptide design and characterization}

The N- and C-terminally truncated peptides of P5 were designed to have a reduced length while retaining their antimicrobial activities. Six truncated peptides were made by truncating two, four, and six amino acids at the $\mathrm{C}$-terminal or $\mathrm{N}$-terminal ends of P5. The net charges of the truncated peptides ranged from +6 to +8 , and they had lower charges than the parent peptide (Table 1). The three-dimensional conformation of P5 and the truncated peptides are shown in Fig. 1a. P5, P5-CT1, and P5-NT1 had a random coil structure between two $\alpha$-helix structures. P5-CT2 and P5-CT3 showed a short $\alpha$-helical structure in the $\mathrm{N}$-terminus and a long random coil structure at the C-terminus. Additionally, P5-NT2 and P5-NT3 had $\alpha$-helical structures.

\section{Structure of Peptides in Various Environments}

To investigate the secondary structure of P5 and the truncated peptides in various membrane mimicking environments (Ma et al. 2015), such as SDS (negatively charged prokaryotic membrane) and TFE (hydrophobic microbial membrane), we obtained CD spectra (Fig. 1b). The CD spectra indicated that P5 and the truncated peptides had a positive peak at $212 \mathrm{~nm}$ and negative dichroic band at $195 \mathrm{~nm}$ in $10 \mathrm{mM}$ SP buffer (pH 7.2). Therefore, $\mathrm{P} 5$ and the truncated peptides had a random coil conformation in $10 \mathrm{mM}$ SP buffer ( $\mathrm{pH}$ 7.2). P5, P5-CT1, P5-NT1, P5-NT2, and P5-NT3 exhibited a positive peak at $190 \mathrm{~nm}$ and two negative dichroic bands at approximately 208 and $222 \mathrm{~nm}$, revealing a $\alpha$-helical conformation in $30 \mathrm{mM}$ SDS and 50\% TFE. In contrast, P5-CT2 and P5-CT3 exhibited random coil conformations in the two solutions, with a positive peak at $212 \mathrm{~nm}$ and negative dichroic band at $195 \mathrm{~nm}$. Similarly, P5, P5-CT1, P5-NT1, P5-NT2, and P5-NT3 revealed an $\alpha$-helical conformation at the presence LTA and LPS, while P5-CT2 and P5-CT3 showed a random coil conformation in both LTA and LPS (Fig. 1c).

\section{Biological activity of peptides}

The antimicrobial activity of P5 and the truncated peptides against Gram-negative bacteria ( $P$. aeruginosa

Table 1 Amino acid sequences and physicochemical parameters of parent and truncation peptides

\begin{tabular}{llllll}
\hline Peptides & Sequences & Measured MW & Theoretical MW & Net charge & Retention time \\
\hline P5 & KWKKLLKKPLLKKLLKKL-NH & 2246.0 & 2245.4 & +9 & 17.425 \\
P5-CT1 & KWKKLLKKPLLKKLLK-NH 2 & 2004.7 & 2004.1 & +8 & 19.250 \\
P5-CT2 & KWKKLLKKPLLKKL-NH 2 & 1763.4 & 1763.0 & +7 & 17.925 \\
P5-CT3 & KWKKLLKKPLLK-NH 2 & 1521.5 & +6 & 17.075 \\
P5-NT1 & KKLLKKPLLLKKLLKKL-NH & 1522.0 & 1931.7 & +8 & 18.517 \\
P5-NT2 & LLKKPLLKKLLKKL-NH & 1931.6 & 1675.3 & +6 & 17.825 \\
P5-NT3 & KKPLLKKLLKKL-NH & 1675.3 & 1449.1 & +6 & 18.067 \\
\hline
\end{tabular}

MW molecular weight, CT C-terminus, NT N-terminus

(See figure on next page.)

Fig. 1 Structural analysis of P5 and its analog peptides. a Three-dimensional structure of P5 and its analogue peptides. b Circular dichroism (CD) spectra of P5 and its analog peptides were measured in various environments. The peptide concentration was t $80 \mu \mathrm{M}$. $\mathbf{c}$ Interaction of P5 and its analog peptides with in $500 \mu \mathrm{g} / \mathrm{mL}$ lipoteichoic acid (LTA) and lipopolysaccharide (LPS). CT C-terminus, NT N-terminus, SP sodium phosphate, TFE trifluoroethanol 


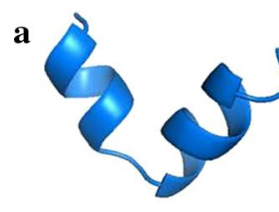

P5

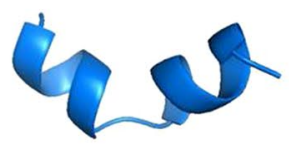

P5-CT1

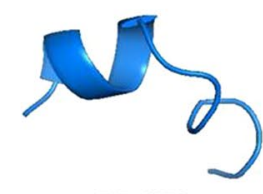

P5-CT2

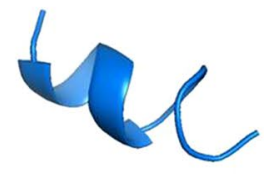

P5-CT3

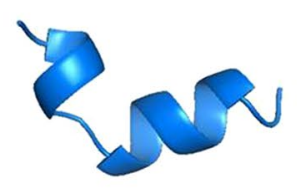

P5-NT1

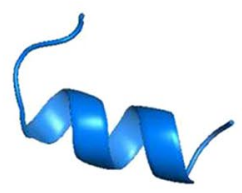

P5-NT2

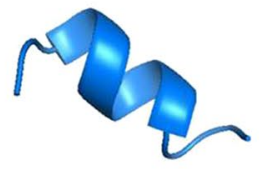

P5-NT3
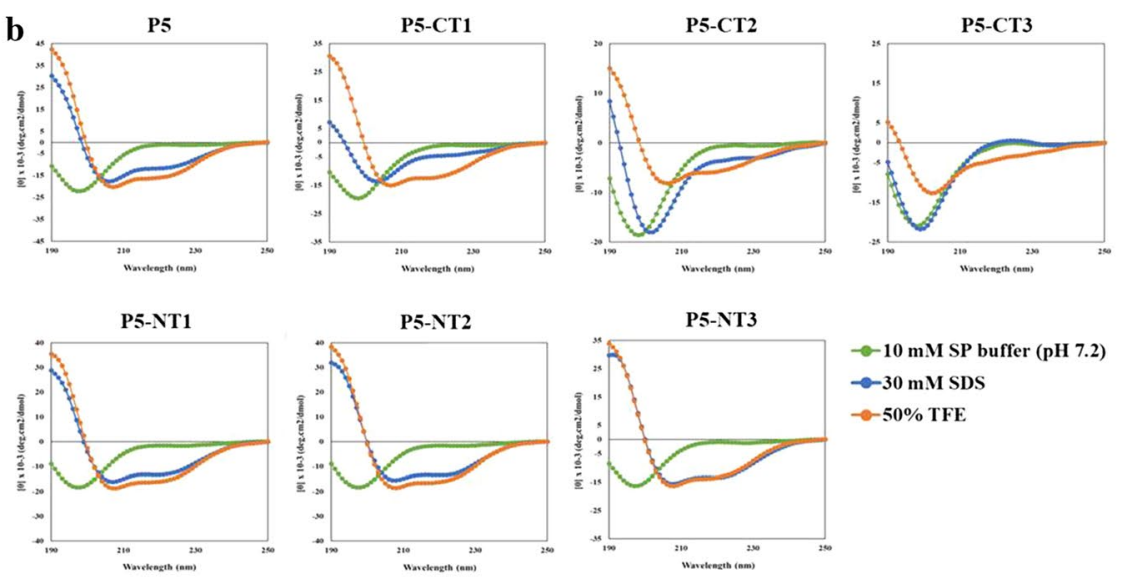

- $-10 \mathrm{mM}$ SP buffer (pH 7.2)

$-30 \mathrm{mM}$ SDS

$-50 \%$ TFE
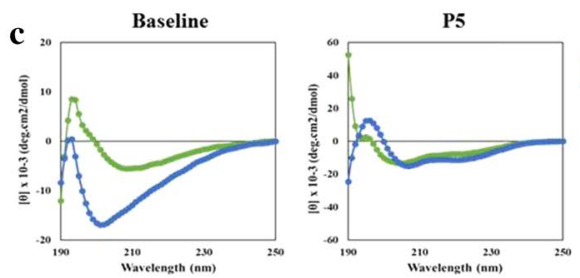

$\rightarrow$ LTA

P5-CT1
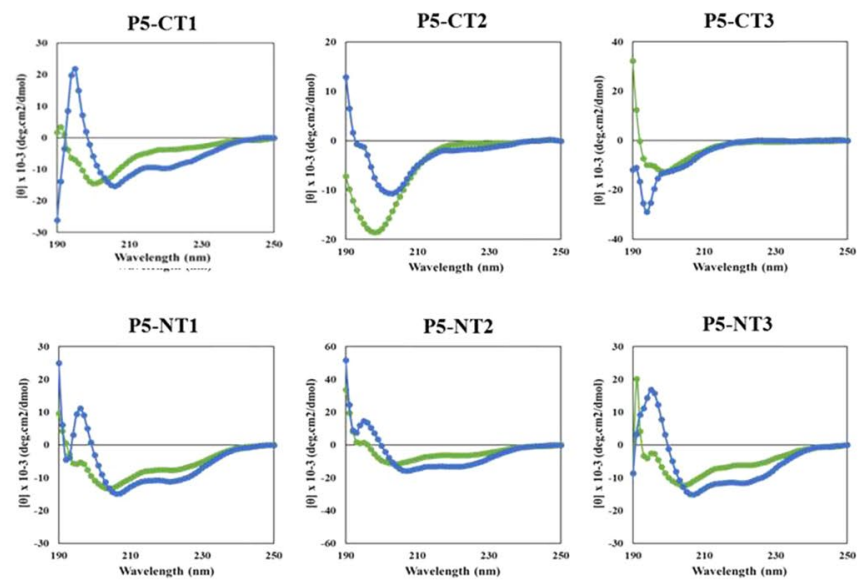
Table 2 Minimum inhibitory concentrations (MICs) of peptides

\begin{tabular}{|c|c|c|c|c|c|c|c|c|}
\hline & \multicolumn{8}{|c|}{$\mathrm{MIC}(\mu \mathrm{M})$} \\
\hline & P5 & P5-CT1 & P5-CT2 & P5-CT3 & P5-NT1 & P5-NT2 & P5-NT3 & Melittin \\
\hline \multicolumn{9}{|l|}{ Gram-negative bacteria } \\
\hline P. aeruginosa ATCC 27853 & 3.13 & 1.56 & 6.25 & $>25$ & 1.56 & 3.13 & 6.25 & 3.13 \\
\hline A. baumannii KCTC 2508 & 1.56 & 3.13 & 12.5 & $>25$ & 3.13 & 12.5 & 25 & 1.56 \\
\hline \multicolumn{9}{|l|}{ Gram-positive bacteria } \\
\hline S. aureus ATCC 25923 & 1.56 & 1.56 & 1.56 & 3.13 & 1.56 & 1.56 & 1.56 & 0.78 \\
\hline B. subtilis KCTC 2217 & 1.56 & 1.56 & 3.13 & 6.25 & 1.56 & 1.56 & 1.56 & 0.78 \\
\hline
\end{tabular}

CT C-terminus, $N T \mathrm{~N}$-terminus

ATCC 27853 and A. baumannii KCTC 2508) and Grampositive bacteria (S. aureus ATCC 25923 and B. subtilis KCTC 2217) were determined using the MIC test (Table 2). The parent peptide showed high antimicrobial activity, with MIC values of 1.56 and $3.13 \mu \mathrm{M}$ against Gram-negative and Gram-positive bacteria, respectively. Similarly, the antimicrobial activities of P5-CT1 and P5-NT1 were high, with MIC values 1.56 and $3.13 \mu \mathrm{M}$, respectively. P5-CT2, P5-CT3, P5-NT2, and P5-NT3 showed low antimicrobial activities against Gram-negative bacteria compared with those against gram-positive bacteria, and exhibited low MIC values against grampositive bacteria, ranging from 1.56 to $6.25 \mu \mathrm{M}$. P5-CT3 had no antimicrobial activity against Gram-negative bacteria.

To investigate the antibacterial effect of the peptides, we performed time-kill kinetic experiments (Fig. 2). The time-kill kinetic curves of peptides against $P$. aeruginosa ATCC 27853 and S. aureus ATCC 25923 were determined at $1 \times$ MIC and $2 \times$ MIC. The results showed that killing of $P$. aeruginosa ATCC 27853 occurred more rapidly than that of $S$. aureus ATCC 25923. P. aeruginosa ATCC 27853 was killed within $5 \mathrm{~min}$ at $2 \times$ MIC and within $60 \mathrm{~min}$ at $1 \times \mathrm{MIC}$ after exposure to P5 and the truncated peptides (except for P5-CT3). However, $S$. aureus ATCC 25923 was killed after $6 \mathrm{~h}$ at $2 \times \mathrm{MIC}$ and after $10 \mathrm{~h}$ at $1 \times$ MIC following the addition P5 and the truncated peptides. The antimicrobial activities of P5 and the truncated peptides were dose- and time-dependent.

To assess the anti-biofilm activity of the peptides, we formed biofilms in the presence of P5 and the truncated peptides (Fig. 3). The results showed that biofilm formation by $P$. aeruginosa ATCC 27853 was inhibited at low concentrations of P5 and the truncated peptides; however, P5-CT3 showed no anti-biofilm activity. P5-CT1 and P5-NT1 showed the highest anti-biofilm activities against $P$. aeruginosa ATCC 27853 among all tested peptides. The minimal anti-biofilm inhibitory concentration (MBIC) values of P5 and the truncated peptides (except
P5-CT3) against $P$. aeruginosa ATCC 27853 ranged from 6.25 to $25 \mu \mathrm{M}$. Additionally, S. aureus ATCC 25923 exhibited higher anti-biofilm activity and the MBIC values of P5 and the truncated peptides against $S$. aureus ATCC 25923 ranged from 3.13 to $12.5 \mu \mathrm{M}$.

\section{Hemolytic activity and cytotoxicity of peptides}

The toxicities of the peptides were determined as the hemolysis of mouse RBCs (Fig. 4a). The hemolytic activities of the peptides are shown in Fig. 4. The parent peptide caused approximately $14 \%$ hemolysis at $100 \mu \mathrm{M}$, while truncated peptides caused no hemolysis at $100 \mu \mathrm{M}$. Melittin from bee venom (Habermann and Jentsch 1967) was used as a positive control (Steiner 1982; Dempsey 1990) and cause approximately $91 \%$ hemolysis at $12.5 \mu \mathrm{M}$.

The cytotoxicity of P5 and the truncated peptides were assessed against $\mathrm{HaCaT}$ cells using the MTT assay (Fig. 4b). The parent peptide was approximately $70 \%$ toxic at concentrations over $100 \mu \mathrm{M}$, while the truncated peptides showed almost no cytotoxicity at concentrations ranging from 1.56 to $200 \mu \mathrm{M}$. Additionally, Melittin, which was used as a positive control, was highly toxic at $1.56 \mu \mathrm{M}$.

\section{Salt sensitivity}

The activities of some antimicrobial peptides are affected by salt environments; therefore, the salt sensitivity of peptides was confirmed by adding different salts at physiological concentrations (Table 3). The results revealed the MIC values of the peptides in the presence of salts. The MIC of the parent peptide toward P. aeruginosa ATCC 27853 and S. aureus ATCC 25923 did not change in different salts at physiological concentrations. The truncated peptides showed stable antimicrobial activity against $P$. aeruginosa ATCC 27853 in the presence $\mathrm{Na}^{+}$ $(50,100,150 \mathrm{mM})$ and $\mathrm{Fe}^{3+}(1,4,8 \mu \mathrm{M})$ Additionally, P5-CT1 and P5-NT1 showed antimicrobial activity in the presence $\mathrm{Mg}^{2+}(0.5,1,2 \mathrm{mM})$. For $S$. aureus ATCC 

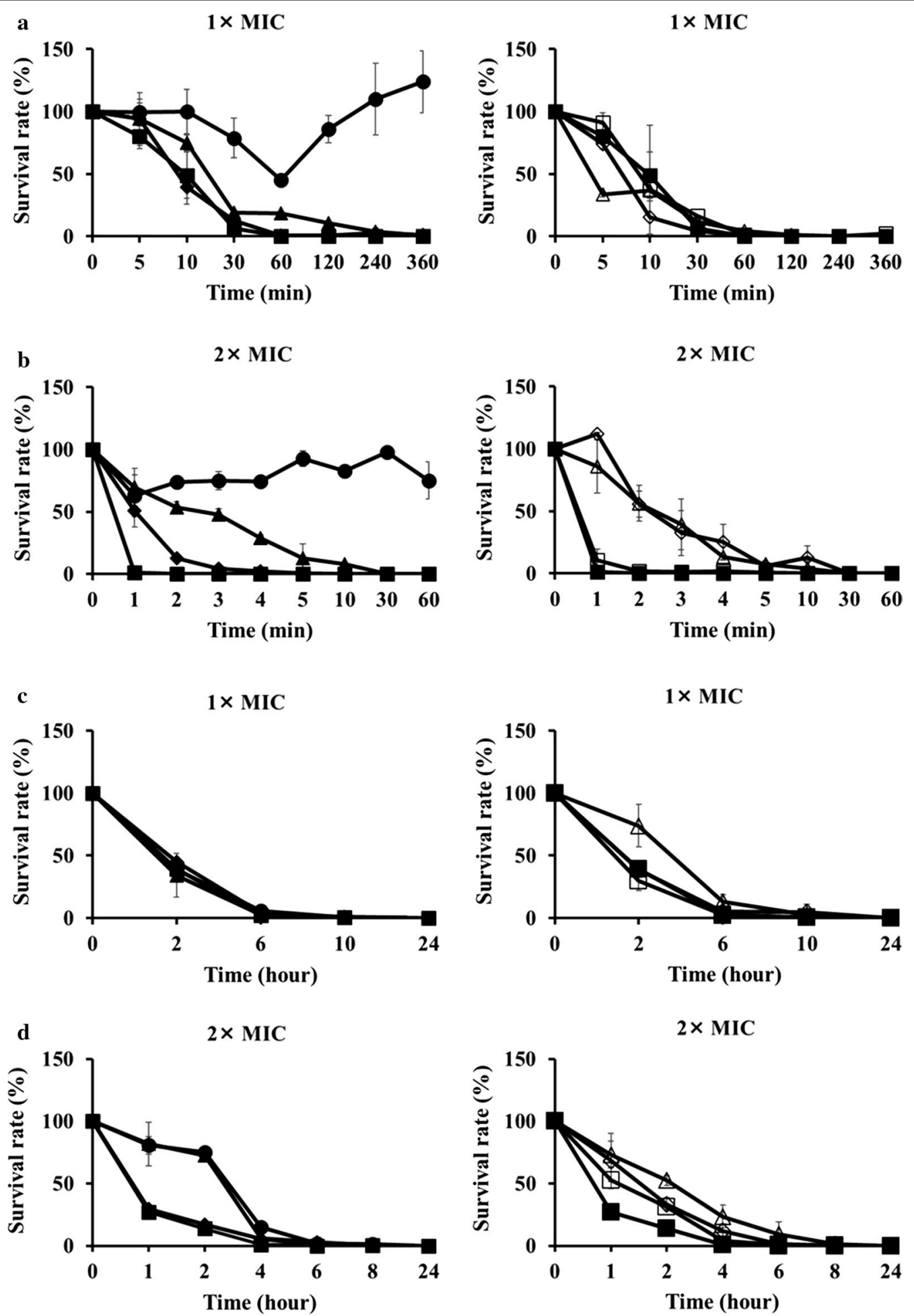

$\rightarrow-\mathrm{P} 5 \multimap \mathrm{P} 5-\mathrm{CT} 1 \multimap \mathrm{P} 5-\mathrm{CT} 2-\mathrm{P} 5-\mathrm{CT} 3 \multimap \mathrm{P} 5-\mathrm{NT} 1 \multimap \mathrm{P5}-\mathrm{NT} 2 \multimap \mathrm{P} 5-\mathrm{NT} 3$

Fig. 2 Time-kill kinetic curves of the peptides. Bactericidal kinetics of P5 and its analog peptides were assessed at $\times 1$ MIC and $\times 2$ MIC. $\mathbf{a}, \mathbf{b} P$. aeruginosa ATCC 27853 and c, d S. aureus ATCC 25923. MIC minimum inhibitory concentration, CT C-terminus, NT N-terminus 

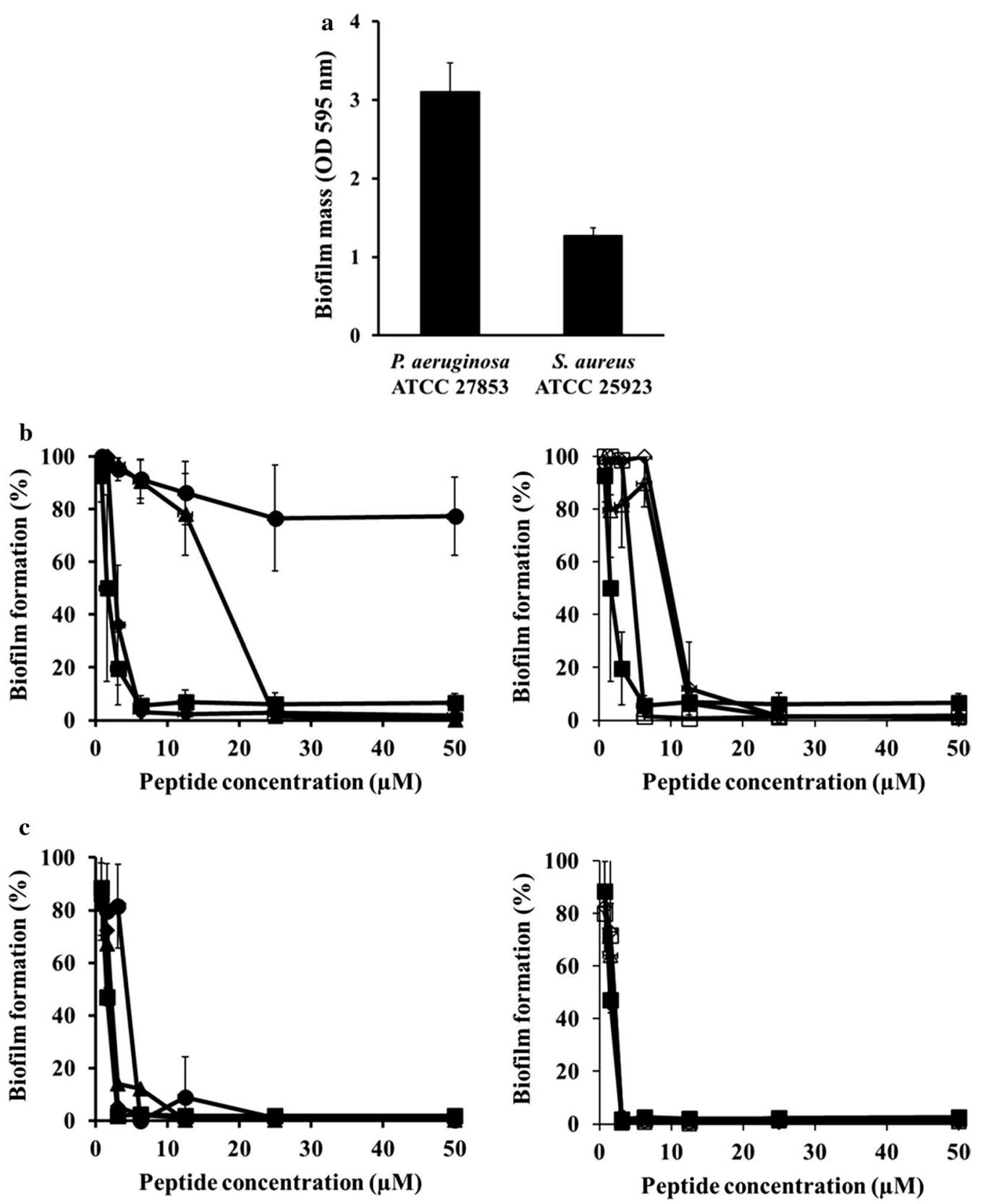

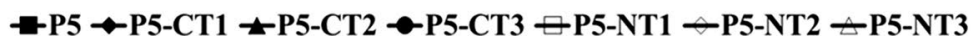

Fig. 3 Inhibition of bacterial biofilm formation by the parent peptide and analog peptides against P. aeruginosa ATCC 27853 and S. aureus ATCC 25923. a Biofilm formation by microorganisms detected by crystal violet staining. Anti-biofilm activity of peptides against $\mathbf{b} P$. aeruginosa ATCC 27853 and $\mathbf{c}$ S. aureus ATCC 25923. CT C-terminus, NT N-terminus

25923, the truncated peptides showed stable antimicrobial activity in the presence $\mathrm{Na}^{+}, \mathrm{Mg}^{2+}$, and $\mathrm{Fe}^{3+}$ at all concentrations.

\section{Outer membrane disruption and permeabilization}

We confirmed the membrane disruption and permeabilization by peptides by conducting a PI and NPN uptake assays (Fig. 5). When the bacteria were exposed to P5 or the truncated peptides, the bacterial membrane rapidly became permeable and PI fluorescence increased within 5 min for both $P$. aeruginosa ATCC 27853 and $S$. aureus ATCC 25923 (Fig. 5a, b). Melittin, which is known to cause rapid membrane disruption, also caused a fast increased PI fluorescence. NPN, a hydrophobic probe, 

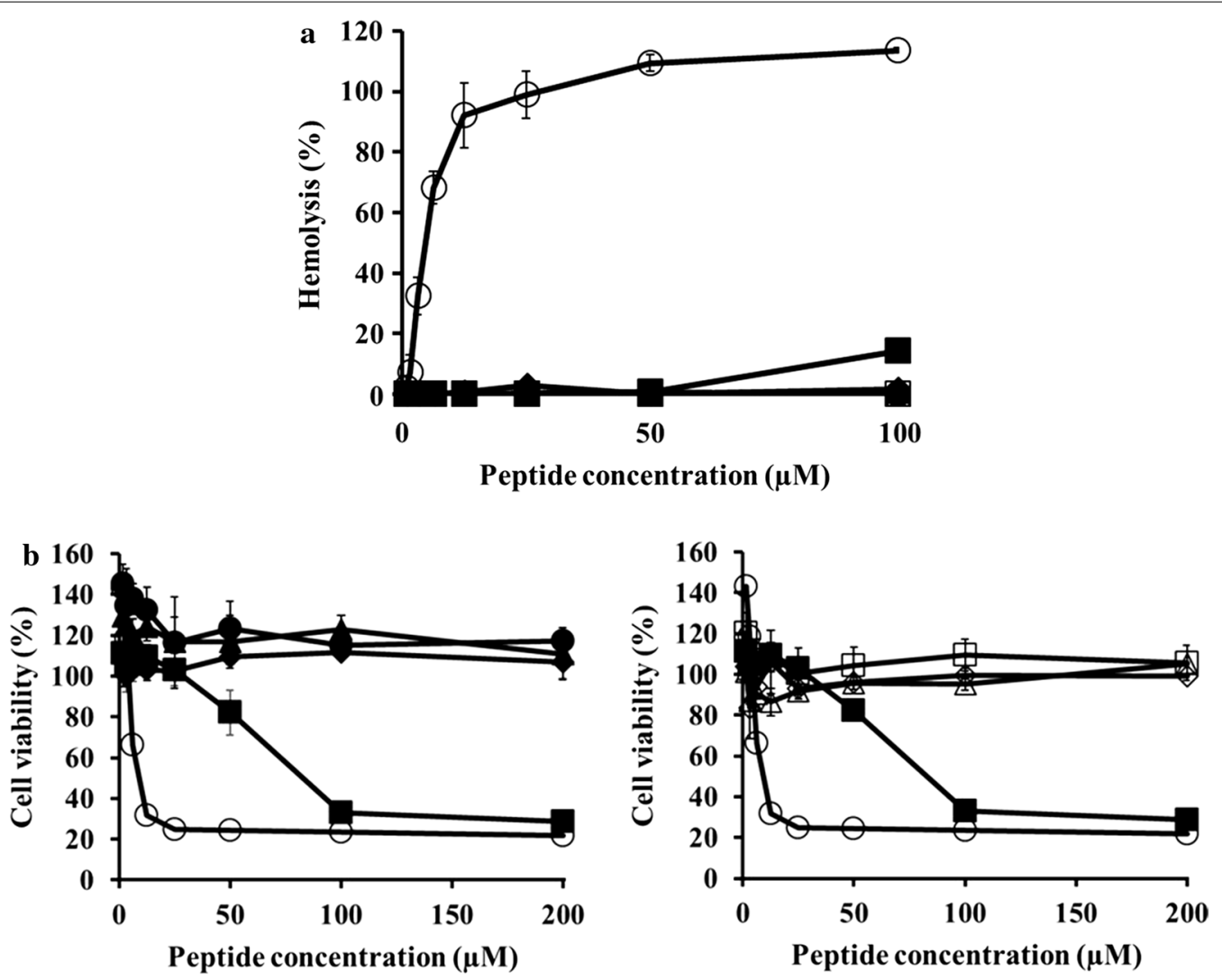

Fig. 4 Hemolytic activity of peptides against mouse red blood cells and cytotoxicity of the peptides against HaCaT cells. a Hemolytic activity of peptides concentrations from 0 to $100 \mu \mathrm{M}$. b Cytotoxicity of peptides concentrations from 0 to $200 \mu \mathrm{M}$. Each experiment was repeated three times. CT C-terminus, NT N-terminus

was used to investigate permeabilization of the outer membrane of gram-negative bacteria (Fig. 5c). When the outer membrane of the bacteria is damaged, NPN uptake increases (Zhu et al. 2014). P5 and the truncated peptides increased NPN uptake by approximately $50 \%$ within $5 \mathrm{~min}$. These results suggested that P5 and the truncated peptides caused membrane disruption to both $P$. aeruginosa ATCC 27853 and S. aureus ATCC 25923 and permeabilized the outer membrane of $P$. aeruginosa ATCC 27853.

\section{Cytoplasmic membrane depolarization}

$\mathrm{DisC}_{3}-5$, a membrane potential-sensitive cationic probe, was used to assess bacterial cytoplasmic membrane depolarization. DisC $_{3}-5$ concentrates in the cytoplasmic membrane and upon membrane disruption, is released into the buffer (Dong et al. 2014) (Fig. 6). The resulting increase in fluorescence can be detected by fluorescence spectrometry. After $5 \mathrm{~min}$ of stabilization, the peptides were added to each well and fluorescence was measured for $30 \mathrm{~min}$. The results showed that the fluorescence increased in the presence of P5 and the truncated peptides over time in P. aeruginosa ATCC 27853 (Fig. 6a). In S. aureus ATCC 25923, except for P5-CT2 and P5-CT3, cytoplasmic membrane depolarization was induced within 5 min by P5 and the truncated peptides (Fig. 6b).

\section{Flow cytometry analysis}

Based on the MIC values of the peptides, their bacterial membrane disruption abilities were measured using fluorescence activated cell sorting (FACS) (Fig. 7). FACS analysis was conducted to count PI-stained bacteria with membranes that were disrupted by the peptides. After 30 min of treatment with $2 \times$ the MIC of the peptides, bacterial membrane integrity was measured using FACS. In the control (no peptide) for P. aeruginosa ATCC 27853 , only $2 \%$ PI-positive bacteria were detected, while treatment with P5 produced $85.7 \%$ PI-positive bacteria, indicating membrane damage. P5-CT1 stained $86.1 \%$ of cells, P5-CT2 stained 9.1\% of cells, and P5-CT3 stained $1.2 \%$ of cells with PI. P5-NT1, P5-NT2, and P5-NT3 showed values of $87.9 \%, 46.7 \%$, and $28.5 \%$, respectively. 
Table 3 Effect of various concentrations of salt on the antibacterial activity of peptides against P. aeruginosa ATCC 27853 and S. aureus ATCC 25923

\begin{tabular}{|c|c|c|c|c|c|c|c|c|c|c|}
\hline & \multirow{3}{*}{$\begin{array}{l}10 \mathrm{mM} \text { SP buffer } \\
(\mathrm{pH} \mathrm{7.2)}\end{array}$} & \multicolumn{9}{|c|}{$\mathrm{MIC}(\mu \mathrm{M})$} \\
\hline & & \multicolumn{3}{|l|}{$\mathrm{NaCl}$} & \multicolumn{3}{|l|}{$\mathrm{MgCl}_{2}$} & \multicolumn{3}{|l|}{$\mathrm{FeCl}_{3}$} \\
\hline & & $50 \mathrm{mM}$ & $100 \mathrm{mM}$ & $150 \mathrm{mM}$ & $0.5 \mathrm{mM}$ & $1 \mathrm{mM}$ & $2 \mathrm{mM}$ & $1 \mu \mathrm{M}$ & $4 \mu \mathrm{M}$ & $8 \mu \mathrm{M}$ \\
\hline \multicolumn{11}{|c|}{ P. aeruginosa ATCC 27853} \\
\hline P5 & 3.13 & 3.13 & 3.13 & 3.13 & 3.13 & 3.13 & 6.25 & 3.13 & 3.13 & 3.13 \\
\hline P5-CT1 & 1.56 & 3.13 & 3.13 & 3.13 & 6.25 & 6.25 & 12.5 & 3.13 & 3.13 & 3.13 \\
\hline P5-CT2 & 6.25 & 12.5 & 25 & $>25$ & $>25$ & $>25$ & $>25$ & 6.25 & 6.25 & 6.25 \\
\hline P5-CT3 & $>25$ & $>25$ & $>25$ & $>25$ & $>25$ & $>25$ & $>25$ & $>25$ & $>25$ & $>25$ \\
\hline P5-NT1 & 1.56 & 3.13 & 3.13 & 3.13 & 6.25 & 6.25 & 25 & 3.13 & 3.13 & 3.13 \\
\hline P5-NT2 & 3.13 & 6.25 & 6.25 & 12.5 & 12.5 & 25 & $>25$ & 3.13 & 3.13 & 3.13 \\
\hline P5-NT3 & 6.25 & 6.25 & 12.5 & 12.5 & 12.5 & 25 & $>25$ & 6.25 & 6.25 & 6.25 \\
\hline \multicolumn{11}{|c|}{ S. aureus ATCC 25923} \\
\hline P5 & 1.56 & 1.56 & 1.56 & 1.56 & 1.56 & 1.56 & 1.56 & 1.56 & 1.56 & 1.56 \\
\hline P5-CT1 & 1.56 & 0.78 & 0.78 & 0.78 & 0.78 & 0.78 & 0.78 & 0.78 & 0.78 & 0.78 \\
\hline P5-CT2 & 1.56 & 0.78 & 1.56 & 1.56 & 0.78 & 0.78 & 1.56 & 0.78 & 0.78 & 0.78 \\
\hline $\mathrm{P} 5-\mathrm{CT} 3$ & 3.13 & 3.13 & 12.5 & 12.5 & 3.13 & 3.13 & 6.25 & 1.56 & 3.13 & 3.13 \\
\hline P5-NT1 & 1.56 & 0.78 & 0.78 & 0.78 & 0.78 & 0.78 & 0.78 & 0.78 & 0.78 & 0.78 \\
\hline P5-NT2 & 1.56 & 1.56 & 0.78 & 0.78 & 0.78 & 0.78 & 1.56 & 1.56 & 0.78 & 1.56 \\
\hline P5-NT3 & 1.56 & 0.78 & 0.78 & 0.78 & 0.78 & 0.78 & 0.78 & 0.78 & 0.78 & 0.78 \\
\hline
\end{tabular}

MIC minimum inhibitory concentration, CT C-terminus, NT N-terminus

For S. aureus ATCC 25923, the control (no peptide) showed 0.9\% PI-positive bacteria, while the parent peptide (P5) showed 56.0\%. Bacteria treated with P5-CT1, PT-CT2, and P5-CT3 showed $38.9 \%, 17.6 \%$, and $17.1 \%$ PI-staining, respectively. P5-NT1, P5-NT2, and P5-NT3 showed values of $55.0 \%, 49.0 \%$, and $42.4 \%$, respectively. P5-CT1 and P5-NT1 caused similar levels of membrane disruption to P5, although truncated peptide caused less membrane disruption than P5.

\section{Discussion}

The emergence of antibiotic-resistant bacteria is increasing worldwide; therefore, novel antimicrobial agents are required (Burgess 2014). AMPs, which are essential in the innate immune system, have broad-spectrum antimicrobial activities and can overcome the limitations of traditional antibiotic agents (Pathak and Chauhan 2011; Chen et al. 2013). AMPs show potential as novel therapeutic agents to kill antibiotic-resistant bacteria (Mahlapuu et al. 2016). The primary mechanism of action of AMPs is membrane disruption to induce rapid death of bacteria (Ting et al. 2014). However, developing AMPs for therapeutic applications is difficult, and technological hurdles must be overcome, including the peptides' stability in various environments, cell selectivity, and reduction in toxicity (Fox et al. 2012; Haney et al. 2012; Liu et al. 2013; Ting et al. 2014). Therefore, designing AMPs with high antimicrobial activity and low cytotoxicity and hemolytic activity would be useful.

In a previous study, P5, a CA-MA analog peptide, was designed to have an increased net positive charge and hydrophobicity by Lys (positions $4,8,14,15$ ) and Leu (positions 5, 6, 12, 13, 16, 17, 20) substitutions, as well as a flexible region (Gly-Ile-Gly $\rightarrow$ P) substitution. The CA-MA analog peptide P5 parent has stronger antibacterial and antifungal activity, and shows no hemolysis compared with CA-MA (Shin et al. 1998; Park et al. 2003; Mereuta et al. 2014). P5 shows broad-spectrum antimicrobial activity and causes membrane disruption (Park et al. 2003, 2006). Additionally, P5 has low cytotoxicity and hemolytic activity (Park et al. 2003; Ryu et al. 2011).

In the present study, we modified P5 to reduce its length while maintaining its antimicrobial activity. Truncated peptides of P5 were designed such that the 18 amino acids of $\mathrm{P} 5$ were truncated at the $\mathrm{C}$-terminus (P5-CT1, P5-CT2, P5-CT3) or N-terminus (P5-NT1, P5-NT2, P5-NT3). The three-dimensional structures of P5-CT1 and P5-NT1, which were truncated by two amino acids, P5-CT2 and P5-NT2, which were truncated by four amino acids, and P5-CT3 and P5-NT3, which were truncated by six amino acids, were determined (Fig. 1). P5-CT1 and P5-NT1 possessed two $\alpha$-helix structures, while the other truncation peptides had one $\alpha$-helix structure. In particular, P5-CT1 and 

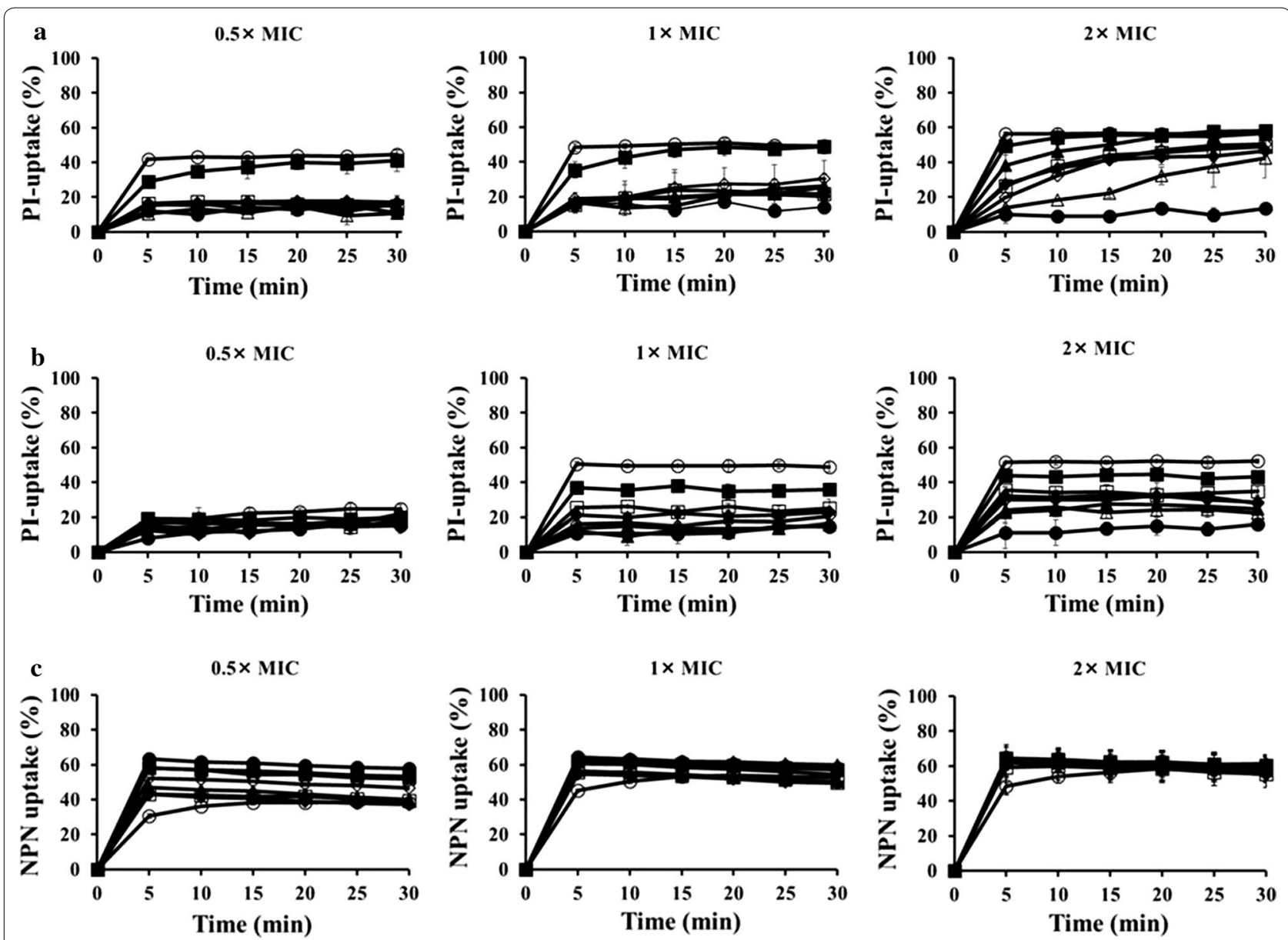

$-\mathrm{P} 5 \multimap \mathrm{P} 5-\mathrm{CT} 1 \multimap \mathrm{P} 5-\mathrm{CT} 2 \multimap \mathrm{P} 5-\mathrm{CT} 3 \multimap \mathrm{P} 5-\mathrm{NT} 1 \multimap \mathrm{P} 5-\mathrm{NT} 2 \multimap \mathrm{P} 5-\mathrm{NT} 3 \multimap$ Melittin

Fig. 5 Membrane disruption and permeabilization. Membrane disruption induced by peptides as detected by PI uptake at $\times 0.5, \times 1$, and $\times 2$ MIC in a P. aeruginosa ATCC 27853 and b S. aureus ATCC 25923. c Outer membrane permeabilization induced by peptides as detected using NPN uptake at $\times 0.5, \times 1$, and $\times 2$ MIC in P. aeruginosa ATCC 27853. PI propidium iodide, MIC minimum inhibitory concentration, NPN n-phenyl-1-naphthylamine, CT C-terminus, NT N-terminus

P5-NT1 showed structures similar to the parent peptide, and P5-CT2 and P5-CT3 showed a more random coiled conformation than an $\alpha$-helical conformation. Thus, the truncated peptides of P5 were classified as amphipathic $\alpha$-helix structure peptides. Additionally, the truncated peptides had lower net positive charges than the parent peptide (Table 1).

Gram-positive bacterial cell walls contain LTA and LPS is an endotoxin found in the outer membrane of Gramnegative bacteria. Cationic amphipathic AMPs can spontaneously insert into the membrane of bacteria, causing disruption (Jamasbi et al. 2014). We measured the peptides' interaction with LTA and LPS (Bhattacharjya and Ramamoorthy 2009) using CD spectra. Figure 1c showed that P5-CT1, P5-NT1, P5-NT2, and P5-NT3 could bind more LTA and LPS than the parent peptide. The peptides could bind to LTA and LPS, which are present on
$S$. aureus and $P$. aeruginos $a$, to form an $\alpha$-helix structure; therefore, we expected that the peptides would bind to the bacterial membrane and cause membrane disruption as their primary antimicrobial mechanism.

The P5 truncated peptides were examined to determine their antimicrobial activity against Gram-negative and Gram-positive bacteria (Table 2). Except for P5-CT3, P5 and the truncated peptides showed antimicrobial activity. In particular, the MICs of P5-CT1 and P5-NT1 were similar to those of the parent peptide. The antimicrobial activity of the truncated peptides against Gram-negative bacteria (P. aeruginosa ATCC 27853 and A. baumannii KCTC 2508) decreased as additional amino acids were removed. P5-CT3, which was truncated by six amino acids, exhibited almost no antimicrobial activity. However, the antimicrobial activity against Gram-negative bacteria decreased when truncation of the C-terminal 


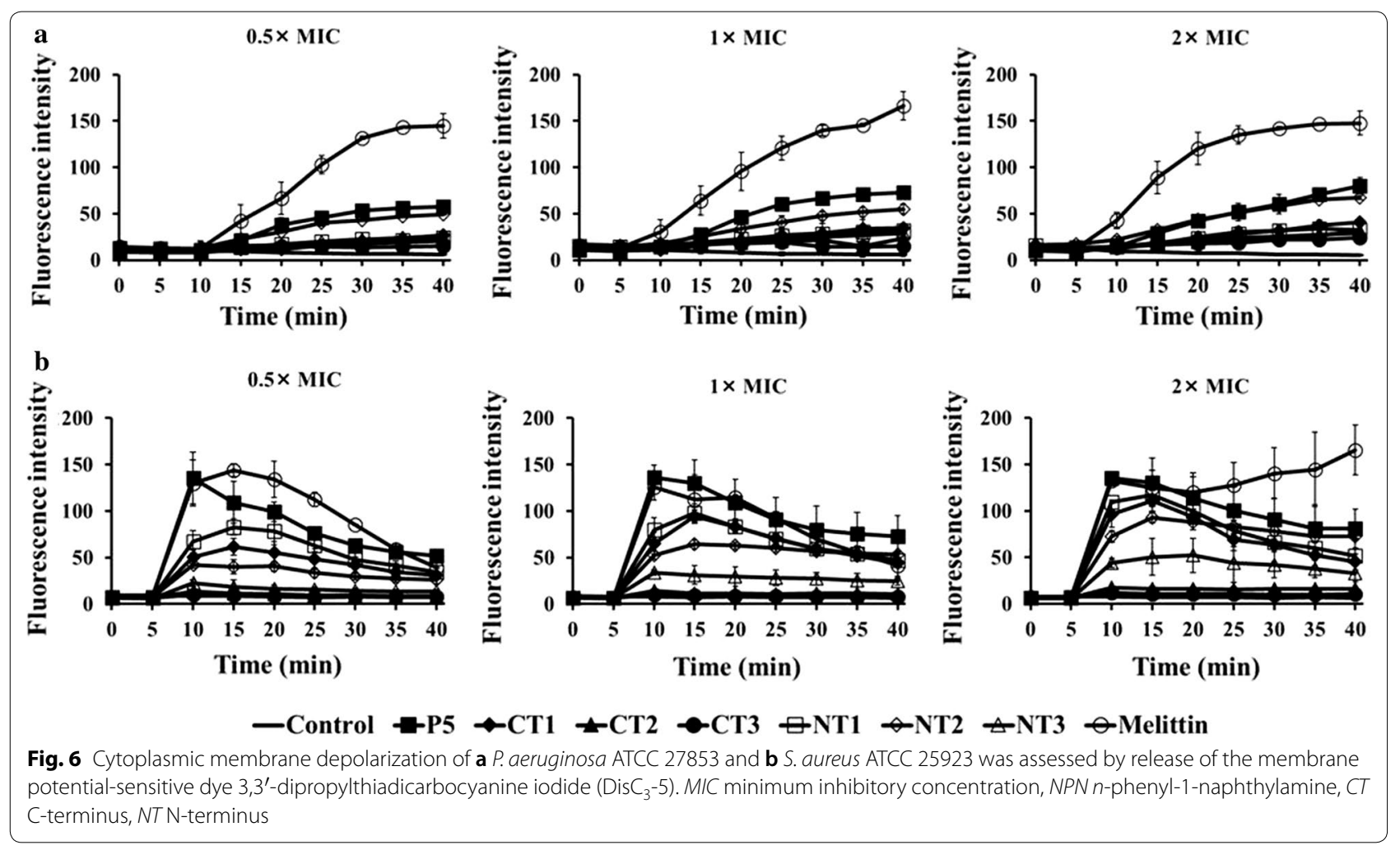

end was greater than that at the $\mathrm{N}$-terminus. In contrast, for C-terminal truncation, the antimicrobial activity against gram-positive bacteria (S. aureus ATCC 25923 and $B$. subtilis KCTC 2217) decreased by more than that of the parent peptide. The antimicrobial activity against Gram-positive bacteria was retained following N-terminal truncation. These results suggested that the C-terminus of P5 is more important than the N-terminus for activity against Gram-negative bacteria, while the C-terminal and $\mathrm{N}$-terminal truncations are equally important for anti-Gram-positive bacteria activity.

Bacterial biofilms are resistant to antibiotic therapy by reducing antibiotic susceptibility and by affecting the host immune systems; therefore, infections involving biofilms are difficult to treat (Bjarnsholt 2013). We investigated the anti-biofilm activity of the peptides. P5-CT1 and P5-NT1 could inhibit biofilm formation at low concentrations, similar to P5 (Fig. 3). We concluded that the P5-CT1 and P5-NT1 showed potential to treat biofilmrelated infections of $P$. aeruginosa and $S$. aureus.

Next, we analyzed the hemolytic activities and cytotoxicities of the truncated peptides. The parent peptide showed hemolytic activity at $100 \mu \mathrm{M}$ and cytotoxicity at $200 \mu \mathrm{M}$ (Fig. 4). Both P5 and the truncated peptides at their MIC levels exhibited no hemolytic activity or cytotoxicity. These results suggested that the truncated peptides of P5 could be developed as safe therapeutic agents.
To develop AMPs as therapeutic agents, several limiting factors must be overcome. The salt sensitivity of AMPs is a major limiting factor in their development as therapeutic agents (Park et al. 2004). The presence of salt cations can affect the antimicrobial activity of AMPs (Huang et al. 2011). Therefore, we investigated the effects of salts on the antimicrobial activity of truncated peptides at various physiological concentrations (Table 3). The parent peptide was not affected by high salt concentration. None of the truncated peptides were sensitive to salt in terms of their activities against $P$. aeruginosa ATCC 27853 and $S$. aureus ATCC 25923; however, the presence of divalent cations caused some sensitivity against $P$. aeruginosa ATCC 27853. Overall, P5 and the truncated peptides were stable in the presence of salt cations, and thus showed potential as therapeutic agents.

Furthermore, we confirmed the mechanism of action of the P5 truncated peptides through PI uptake, NPN uptake, $\mathrm{DisC}_{3}-5$, and FACS assays. All the truncated peptides induced disruption of the outer and inner membranes, and the mechanism of action was the same as that of the parent peptide (Park et al. 2003, 2006). The outer and inner membranes were disrupted by peptides within 5 min. Thus, P5 and the truncated peptides killed bacteria by disrupting the bacteria membrane.

In conclusion, we investigated whether the truncated peptides of P5 retain antimicrobial activity. We confirmed 
Kwon et al. AMB Exp $\quad$ (2019) 9:122

Page 13 of 15
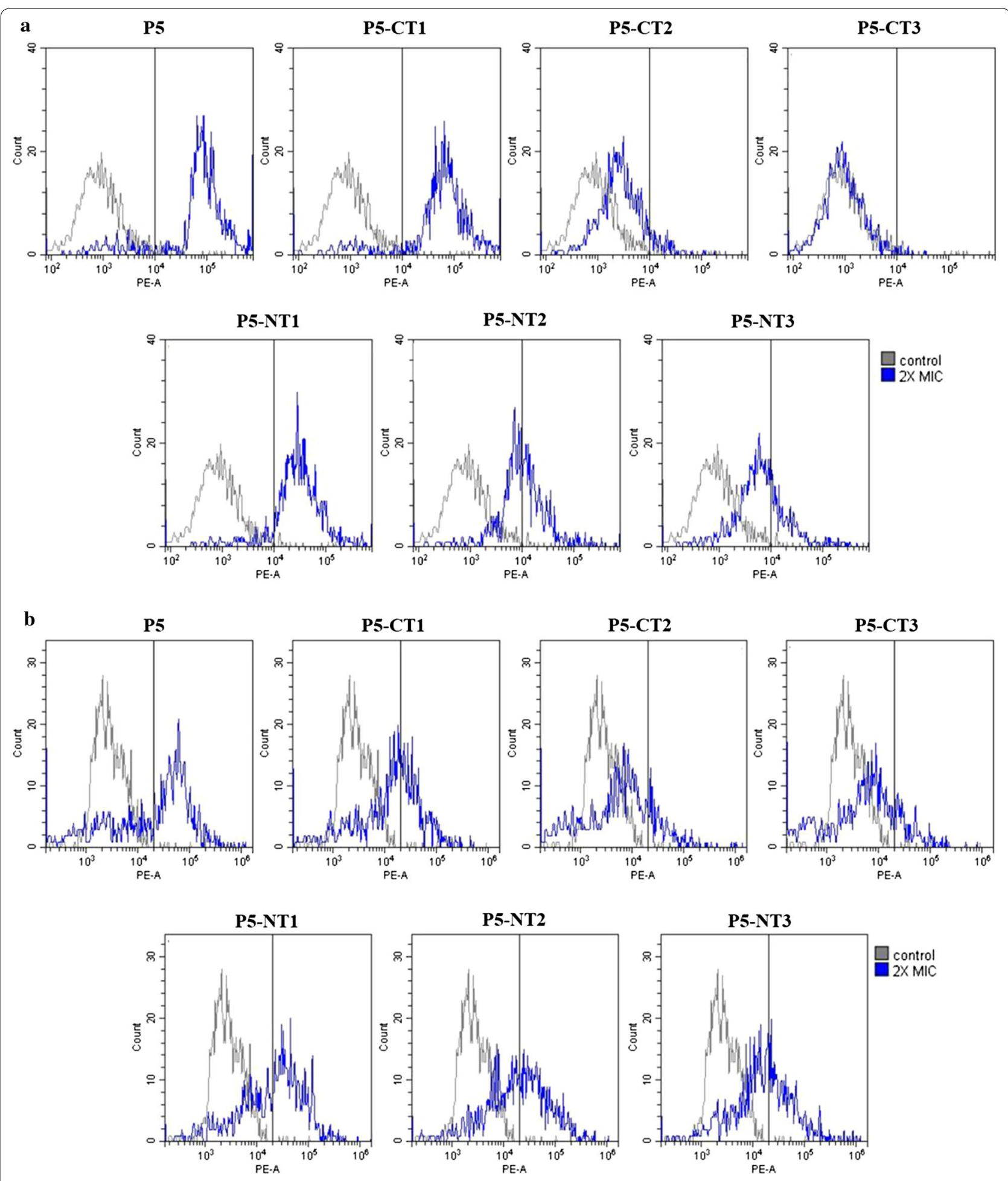

Fig. 7 Flow cytometry analysis. Exponential phase P. aeruginosa ATCC 27853 and S. aureus ATCC 25923 were treated with the peptides, and PI was analyzed by fluorescence activated cell sorting (FACS) flow cytometry. a P. aeruginosa ATCC 27853, b S. aureus ATCC 25923. P/ propidium iodide, MIC minimum inhibitory concentration, NPN n-phenyl-1-naphthylamine, CT C-terminus, NT N-terminus 
that P5-CT1 and P5-NT1, which are truncated by two amino acids at the $\mathrm{C}$-terminus or $\mathrm{N}$-terminus, showed high antimicrobial activity against Gram-negative and Gram-positive bacteria, and no toxicity toward normal human cells compared with P5. The mechanism of action of the truncated peptides involved membrane disruption, the primary mechanism of AMPs. Therefore, as shorter peptides than their parent peptide, P5-CT1 and P5-NT1 would be less costly, and are suggested as potential therapeutic agents.

\section{Acknowledgements}

Not applicable.

\section{Authors' contributions}

JY carried out all experiments and drafted the manuscript. MK, LM, CS and $T L$ made contribution to the revision of the manuscript. YK supervised the project and revised the manuscript. All authors read and approved the final manuscript.

\section{Funding}

Not applicable.

\section{Availability of data and materials}

The data set supporting the conclusions of this article is included within the article. Data and materials can also be requested from the corresponding author.

\section{Ethics approval and consent to participate}

The mice blood in hemolysis assay complied with the guidelines of Institutional Animal Care and Use Committee at Chosun University, and the protocol was approved by the Animal Ethics Committee (CIACUC2017-A0048; Chosun University, Gwangju, South Korea).

\section{Consent for publication}

Not applicable.

\section{Competing interests}

The authors declare that they have no competing interests.

\section{Author details}

${ }^{1}$ Department of Biomedical Science, Chosun University, Gwangju 61452, South Korea. ${ }^{2}$ Department of Physics, Alexandru I. Cuza University, lasi, Romania. ${ }^{3}$ Department of Bioinformatics, Kongju National University, Kongju 314-701, South Korea. ${ }^{4}$ Research Center for Proteineous Materials, Chosun University, Kwangju 61452, South Korea.

Received: 28 April 2019 Accepted: 20 July 2019

Published online: 30 July 2019

\section{References}

Bhattacharjya S, Ramamoorthy A (2009) Multifunctional host defense peptides: functional and mechanistic insights from NMR structures of potent antimicrobial peptides. FEBS J 276(22):6465-6473. https://doi.org/10.111 1/j.1742-4658.2009.07357.x

Bjarnsholt T (2013) The role of bacterial biofilms in chronic infections. APMIS 136:1-51. https://doi.org/10.1111/apm.12099

Brown KL, Hancock RE (2006) Cationic host defense (antimicrobial) peptides. Curr Opin Immunol 18(1):24-30. https://doi.org/10.1016/j.coi.2005.11.004

Burgess DJ (2014) Microbial genetics: amplified origins of antibiotic resistance. Nat Rev Genet 15(6):362. https://doi.org/10.1038/nrg3740

Chen HL, Su PY, Chang YS, Wu SY, Liao YD, Yu HM, Lauderdale TL, Chang K, Shih C (2013) Identification of a novel antimicrobial peptide from human hepatitis B virus core protein arginine-rich domain (ARD). PLoS Pathog 9(6):e1003425. https://doi.org/10.1371/journal.ppat.1003425
Cho E, Lee JK, Park E, Seo CH, Luchian T, Park Y (2018) Antitumor activity of HPA3P through RIPK3-dependent regulated necrotic cell death in colon cancer. Oncotarget 9(8):7902-7917. https://doi.org/10.18632/oncotarget .24083

Dempsey CE (1990) The actions of melittin on membranes. Biochim Biophys Acta 1031(2):143-161

Deng X, Qiu Q, Yang B, Wang X, Huang W, Qian H (2015) Design, synthesis and biological evaluation of novel peptides with anti-cancer and drug resistance-reversing activities. Eur J Med Chem 89:540-548. https://doi. org/10.1016/j.ejmech.2014.10.072

Devine DA, Hancock RE (2002) Cationic peptides: distribution and mechanisms of resistance. Curr Pharm Des 8(9):703-714

Dong N, Zhu X, Chou S, Shan A, Li W, Jiang J (2014) Antimicrobial potency and selectivity of simplified symmetric-end peptides. Biomaterials 35(27):8028-8039. https://doi.org/10.1016/j.biomaterials.2014.06.005

Fox MA, Thwaite JE, Ulaeto DO, Atkins TP, Atkins HS (2012) Design and characterization of novel hybrid antimicrobial peptides based on cecropin A, LL-37 and magainin II. Peptides 33(2):197-205. https://doi.org/10.1016/j. peptides.2012.01.013

Habermann E, Jentsch J (1967) Sequence analysis of melittin from tryptic and peptic degradation products. Hoppe Seylers Z Physiol Chem 348(1):37-50

Han FF, Gao YH, Luan C, Xie YG, Liu YF, Wang YZ (2013) Comparing bacterial membrane interactions and antimicrobial activity of porcine lactoferricinderived peptides. J Dairy Sci 96(6):3471-3487. https://doi.org/10.3168/ jds.2012-6104

Han HM, Gopal R, Park Y (2016) Design and membrane-disruption mechanism of charge-enriched AMPs exhibiting cell selectivity, high-salt resistance, and anti-biofilm properties. Amino Acids 48(2):505-522. https://doi. org/10.1007/s00726-015-2104-0

Hancock RE, Sahl HG (2006) Antimicrobial and host-defense peptides as new anti-infective therapeutic strategies. Nat Biotechnol 24(12):1551-1557. https://doi.org/10.1038/nbt1267

Haney EF, Nazmi K, Bolscher JG, Vogel HJ (2012) Structural and biophysical characterization of an antimicrobial peptide chimera comprised of lactoferricin and lactoferrampin. Biochim Biophys Acta 1818(3):762-775. https ://doi.org/10.1016/j.bbamem.2011.11.023

Huang J, Hao D, Chen Y, Xu Y, Tan J, Huang Y, Li F, Chen Y (2011) Inhibitory effects and mechanisms of physiological conditions on the activity of enantiomeric forms of an a-helical antibacterial peptide against bacteria. Peptides 32(7):1488-1495. https://doi.org/10.1016/j.peptides.2011.05.023

Jamasbi E, Batinovic S, Sharples RA, Sani MA, Robins-Browne RM, Wade JD, Separovic F, Hossain MA (2014) Melittin peptides exhibit different activity on different cells and model membranes. Amino Acids 46(12):2759-2766. https://doi.org/10.1007/s00726-014-1833-9

Jenssen H, Hamill P, Hancock RE (2006) Peptide antimicrobial agents. Clin Microbiol Rev 19(3):491-511. https://doi.org/10.1128/CMR.00056-05

Jorgensen JH (1993) Antimicrobial susceptibility testing of bacteria that grow aerobically. Infect Dis Clin North Am 7(2):393-409

Kim MK, Kang HK, Ko SJ, Hong MJ, Bang JK, Seo CH, Park Y (2018) Mechanisms driving the antibacterial and antibiofilm properties of Hp1404 and its analogue peptides against multidrug-resistant Pseudomonas aeruginosa. Sci Rep 8(1):1763. https://doi.org/10.1038/s41598-018-19434-7

Lehrer RI, Ganz T (1999) Antimicrobial peptides in mammalian and insect host defence. Curr Opin Immunol 11(1):23-27

Liu Y, Xia X, Xu L, Wang Y (2013) Design of hybrid $\beta$-hairpin peptides with enhanced cell specificity and potent anti-inflammatory activity. Biomaterials 34(1):237-250. https://doi.org/10.1016/j.biomaterials.2012.09.032

Loh B, Grant C, Hancock RE (1984) Use of the fluorescent probe 1-N-phenylnaphthylamine to study the interactions of aminoglycoside antibiotics with the outer membrane of Pseudomonas aeruginosa. Antimicrob Agents Chemother 26(4):546-551

Ma Z, Wei D, Yan P, Zhu X, Shan A, Bi Z (2015) Characterization of cell selectivity, physiological stability and endotoxin neutralization capabilities of a-helix-based peptide amphiphiles. Biomaterials 52:517-530. https://doi. org/10.1016/j.biomaterials.2015.02.063

Mahlapuu M, Hakansson J, Ringstad L, Bjorn C (2016) Antimicrobial peptides: an emerging category of therapeutic agents. Front Cell Infect Microbiol 6:194. https://doi.org/10.3389/fcimb.2016.00194 
Mendez-Samperio P (2013) Recent advances in the field of antimicrobial peptides in inflammatory diseases. Adv Biomed Res 2:50. https://doi. org/10.4103/2277-9175.114192

Mereuta L, Roy M, Asandei A, Lee JK, Park Y, Andricioaei I, Luchian T (2014) Slowing down single-molecule trafficking through a protein nanopore reveals intermediates for peptide translocation. Sci Rep 4:3885. https:// doi.org/10.1038/srep03885

Nawrot R, Barylski J, Nowicki G, Broniarczyk J, Buchwald W, Gozdzicka-Jozefiak A (2014) Plant antimicrobial peptides. Folia Microbiol (Praha) 59(3):181196. https://doi.org/10.1007/s12223-013-0280-4

Nguyen LT, Haney EF, Vogel HJ (2011) The expanding scope of antimicrobial peptide structures and their modes of action. Trends Biotechnol 29(9):464-472. https://doi.org/10.1016/j.tibtech.2011.05.001

Oh D, Shin SY, Lee S, Kang JH, Kim SD, Ryu PD, Hahm KS, Kim Y (2000) Role of the hinge region and the tryptophan residue in the synthetic antimicrobial peptides, cecropin A(1-8)-magainin 2(1-12) and its analogues, on their antibiotic activities and structures. Biochemistry 39(39):11855-11864

Park DG, Jang SH, Woo ER, Jeong HG, Choi CH, Hahm KS (2003) A Leu-Lys-rich antimicrobial peptide: activity and mechanism. Biochim Biophys Acta 1645(2):172-182

Park IY, Cho JH, Kim KS, Kim YB, Kim MS, Kim SC (2004) Helix stability confers salt resistance upon helical antimicrobial peptides. J Biol Chem 279(14):13896-13901. https://doi.org/10.1074/jbc.M311418200

Park Y, Park SN, Park SC, Shin SO, Kim JY, Kang SJ, Kim MH, Jeong CY, Hahm KS (2006) Synergism of Leu-Lys rich antimicrobial peptides and chloramphenicol against bacterial cells. Biochim Biophys Acta 1764(1):24-32. https://doi.org/10.1016/j.bbapap.2005.10.019

Pathak S, Chauhan VS (2011) Rationale-based, de novo design of dehydrophenylalanine-containing antibiotic peptides and systematic modification in sequence for enhanced potency. Antimicrob Agents Chemother 55(5):2178-2188. https://doi.org/10.1128/AAC.01493-10

Radek K, Gallo R (2007) Antimicrobial peptides: natural effectors of the innate immune system. Semin Immunopathol 29(1):27-43

Ryu S, Choi SY, Acharya S, Chun YJ, Gurley C, Park Y, Armstrong CA, Song PI, Kim BJ (2011) Antimicrobial and anti-inflammatory effects of Cecropin A(18)-Magainin2(1-12) hybrid peptide analog P5 against Malassezia furfur infection in human keratinocytes. J Invest Dermatol 131(8):1677-1683. https://doi.org/10.1038/jid.2011.112

Ryu S, Han HM, Song PI, Armstrong CA, Park Y (2015) Suppression of Propionibacterium acnes infection and the associated inflammatory response by the antimicrobial peptide P5 in mice. PLoS ONE 10(7):e0132619. https:// doi.org/10.1371/journal.pone.0132619

Shin SY, Kang JH, Lee MK, Kim SY, Kim Y, Hahm KS (1998) Cecropin Amagainin 2 hybrid peptides having potent antimicrobial activity with low hemolytic effect. Biochem Mol Biol Int 44(6):1119-1126

Steiner H (1982) Secondary structure of the cecropins: antibacterial peptides from the moth Hyalophora cecropia. FEBS Lett 137(2):283-287

Steiner H, Hultmark D, Engstrom A, Bennich H, Boman HG (2009) Sequence and specificity of two antibacterial proteins involved in insect immunity. Nature 292:246-248

Takahashi D, Shukla SK, Prakash O, Zhang G (2010) Structural determinants of host defense peptides for antimicrobial activity and target cell selectivity. Biochimie 92(9):1236-1241. https://doi.org/10.1016/j.biochi.2010.02.023

Ting CH, Huang HN, Huang TC, Wu CJ, Chen JY (2014) The mechanisms by which pardaxin, a natural cationic antimicrobial peptide, targets the endoplasmic reticulum and induces c-FOS. Biomaterials 35(11):36273640. https://doi.org/10.1016/j.biomaterials.2014.01.032

van Hoek ML (2014) Antimicrobial peptides in reptiles. Pharmaceuticals (Basel) 7(6):723-753. https://doi.org/10.3390/ph7060723

Zasloff M (1987) Magainins, a class of antimicrobial peptides from Xenopus skin: isolation, characterization of two active forms, and partial cDNA sequence of a precursor. Proc Natl Acad Sci USA 84(15):5449-5453

Zhu X, Dong N, Wang Z, Ma Z, Zhang L, Ma Q, Shan A (2014) Design of imperfectly amphipathic a-helical antimicrobial peptides with enhanced cell selectivity. Acta Biomater 10(1):244-257. https://doi.org/10.1016/j.actbi 0.2013 .08 .043

\section{Publisher's Note}

Springer Nature remains neutral with regard to jurisdictional claims in published maps and institutional affiliations.

\section{Submit your manuscript to a SpringerOpen ${ }^{\circ}$ journal and benefit from:}

- Convenient online submission

- Rigorous peer review

- Open access: articles freely available online

- High visibility within the field

- Retaining the copyright to your article

Submit your next manuscript at springeropen.com 